\title{
Diminishing Species
}

\section{By ARTHUR WARD, Swift Current}

The 50th anniversary of the Province reveals many changes in respect to wild life on the prairie. Many species have almost completely disappeared from our district, though where the habitat has proved more favorable for their needs, they still can be seen further north.

The shy Kit Fox, its yapping bark heard every night, numerous then and always cautious in providing at least three exits from its shallow den, quickly retreated to other secluded areas.

Chestnut-coloured Longspurs in their thousands filled the air with song as they soared up, returning downwards with wings over back. Only in pasture lands are these now seen - and in depleted numbers.

The Prairie Chicken have retreated to the scrub areas and are no longer heard booming in the early morning. Very noticeable too is the decrease of the Hungarian Partridge which in its early introduction seemed to have difficulty in avoiding the barbwire fences during flight. Many were often seen lying in the ditches by the roadside.

With the exclusion of the coyote from our territory it was expected that the gopher would be seen in much larger numbers but the extreme wet weather has greatly reduced them by drowning them out. Jack Rabbits, too, are not often seen. Considered a delicacy by the old homesteaders before, they were afflicted by parasitic blisters. The badger also, its presence marked by numerous dirt mounds, is in the declining state.

Circumstances prevailing, caused by wet weather, do not allow for full concentration of migrant birds in the groves of prairie sanctuaries, thereby eliminating the banding of the much rarer species. For the first time in our observation not one of the Olive-backed, Grey-cheeked a n d Hermit Thrushes was seen in migration last fall.

The absence of many otherwise usual species is giving cause for alarm, and has been very disappointing to the bira bander. Returning from the farm on two occasions, during the early fall evesings, it was amazing to see millions of gnatsize insects flying in front of the car. For fourteen miles the edge of the road was flanked by weeds, three feet tall. These may have caused the insects to congregate there.

\section{Nature Notes from Crocus}

North of Minnedosa, on Clear Lake Highway

by Mrs. Ellen Averill

After a short spell of winter in October and real seasonable weather in November, we enjoyed an unusually mild climate in December, sometimes scarcely freezing, which has lasted well on into the New Year. The bright sunshine, warming up the daytime proved a boon to the farmers whose work was much delayed by the inclement fall. They were able to finish out small pieces of: breaking in late November, and do feed cutting in comparative comfort in December.

Albinos have been noticed here; a white swallow was seen several times among a number of Tree
Swallows in our yard, and a piebald rat was trapped under the granary. (Incidentally our farm was named "Swallowdale" before I came to it on account of the large numbers of these birds always around. Eave Swallows just piled their nests under the eaves of the barn and granary, and Tree Swallows were equally abundant in the bluffs. Now swallows almost hide the telephone and hydro wires, when they gather in late summer).

Muskrats seem far more abundant than in recent years, every little slough and hay meadow has its quota of rat hills and many have been trapped. More ravens have been seen than I ever remember before; many people take them for crows, but their wing-spread is larger and their call hoarser.

(Continued on Page 21) 


\title{
Battle to Death
}

\author{
CLIFF SHAW, Yorkton
}

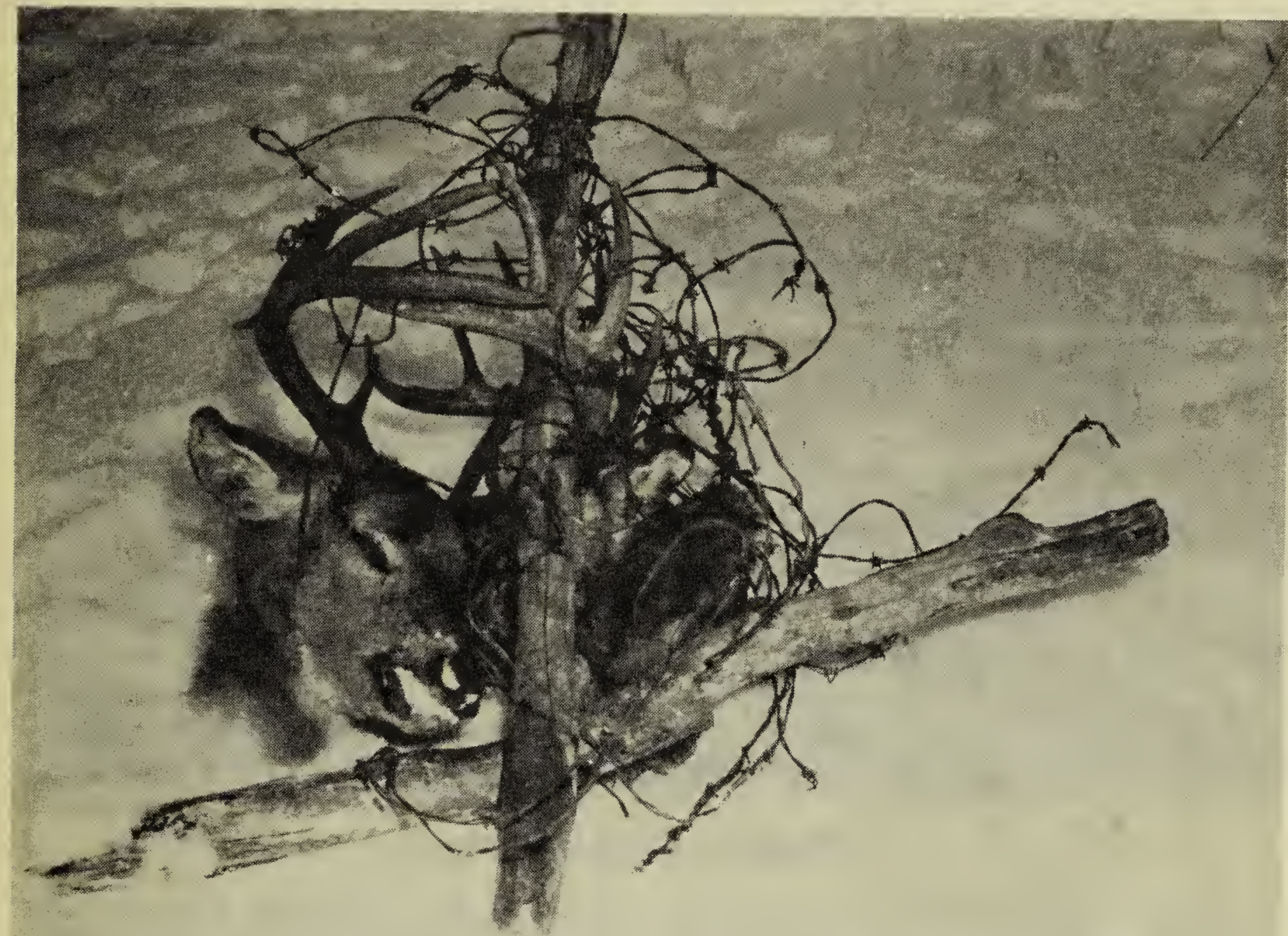

Poem by Dr. H. S. Swallow, Yorkton.

Evidence of one of nature's struggles for existence are these two deer heads, locked in battle and entwined with over 50 feet of barbed wire and two fence posts. The animals were found by Norman Allan on the farm of Alex Phelps in the Crescent Lake district, south of Yorkton. The two bucks, one a four-pointer and the other a five, had apparently started their argument on either side of a farm fence. In their battle to death they tore up almost 100 feet of fence line and in their struggle wrapped half of it around their horns.

They fought for mastery and the right

To lead the herd and propogate their kind.

But, blind, mad, passion posed as fate,

Locked horns and cruel wire both did bind.
Dumb animals, we lightly say, and go our way,

And leave their forms within that quiet glen -

Forgetting, just how often, blind, mad passion wrecks

The lives of some who pose, as wiser men.

Nature Notes (from Page 7)

Bohemian Waxwings, generally seen in small flocks, are with us by the hundreds. Pine Grosbeaks and Evening Grosbeaks are also quite numerous. The latter are especially welcome as they prevent our being overhwhelmed by the Manitoba Maples, many of which are loaded with winged seeds which these beautiful birds eat greedily.

Chickadees and Hairy and Downy Woodpeckers are constant visitors to a maple tree, just outside the kitchen window. 